\title{
Export Performance of Spice Crops and Its Determinants in Ethiopia: VECM Analysis
}

\author{
Abebe Cheffo Degye Goshu
}

\begin{abstract}
Ethiopia, as the case of many developing countries export has been limited to few primary products which are mainly agricultural commodities. From the total exports of the country coffee was the dominant export commodity accounting for about 52.27 per cent of the country's total exports, on average. Spices are essential oils that give foods and beverages flavor, aroma and sometimes color. Ethiopia has reached to production level of spice crops 244,000 ton/annum having area coverage of 122,700 hectares. The objective of this study is to examine spice crops export performance in Ethiopia. In this study, time series secondary data for the period 1992/93 to 2015/16 has been collected from FAOSTAT, IMF database and CoMTRADE data source. The value of spice exported, real exchange rate (official exchange rate), real income and real GDP of partners and Ethiopia in respective order, measured in USD, and openness for trade data was collected from the aforementioned sources. All the data was transformed into natural logarithm form before analysis. The VEC model is very important in the analysis of spice crop export performance of Ethiopia and has proven to be a useful tool in determining export potential of the country. STATA software was utilized to analyze the secondary data obtained from different sources. The time series data that are used in this study are export of spice crops valued in US dollar, real income of trading partner, real GDP of home country valued in USD and openness for trade. Accordingly, in the long run log form of real effective exchange rate, openness to external trade and real GDP are significant at 5 percent level of significant. The short run model output shows these variables are insignificant. The export of Ethiopian spice crop competitiveness also dependent on the effectiveness of real exchange rate. Thus, the government should work hard to keep stable the rate of exchange rate.
\end{abstract}

Keywords: Export, VEC model, time series data, demand

DOI: $10.7176 / \mathrm{JESD} / 11-3-06$

Publication date: February $29^{\text {th }} 2020$

\section{Introduction}

Economic development is one of the main objectives of every society in the world and economic growth is fundamental to economic development. There are many variables that contribute to economic growth. Export is considered as one of the very important accelerators of growth. The economics literature supports the contention that development requires economic growth to alleviate poverty, and greater access to world markets is perceived as a necessary condition for more rapid growth. For example, using cross-sectional regression, Agosin (2007) finds that export diversification has a stronger effect on per capita income growth. The share of international trade to this end by many developing countries was raised from below 25 percent to around 33 percent (Bacchetta, 2007). The lion share of developing counties who diversified the export commodities is taken by China. The same writer also explained that while developing Asia's share in total world exports increased from $11.7 \%$ in 1985 to $21.5 \%$ in 2005 , Africa's share decreased from $4.3 \%$ to $2.9 \%$ over the same period. Different reasons have been forwarded for the main reasons for Africa's poor export performance. For example, Almayehu (2006) and Biggs (2007) stressed that the structure of African exports, which is characterized by dependence on primary commodities, as the main reason.

Even though the overall growth of export in Ethiopia for four decades (1970/71 to 2010/11) was 15.23 percent, which export sector is still small; evidenced by the lower export/GDP ratio and the declining share of exports in import financing. By the year 2011, exports of goods in Ethiopia are only about 7 per cent of GDP, compared to an average of near 30 percent of GDP in Sub-Saharan Africa. Export levels still fall short of what is registered by other African countries with much smaller populations (Uganda and Tanzania both export more than $\$ 3$ billion per year). Growth rates are also very modest if one makes a comparison with Asian countries over a decades-long time frame. The performance of majority of African countries on export expresses very low growth as compare with Asian countries. Accordingly, Ethiopia's total exports were higher than that of Vietnam in the 1980s but are now just a tiny fraction: \$2 billion in Ethiopia versus $\$ 65$ billion in Vietnam (NBE, 2011).

Ethiopia, as the case of many developing countries export has been limited to few primary products which are mainly agricultural commodities. The report of World Bank by the year 2014/15 depicted that primary agricultural commodities took an extreme share of 81 percent of export. In contrast, the manufactures export share was only 19 percent while China is 94 percent. When we look at the last 3 decades export data of the country, the export structure has been characterized by greater concentration on few traditional exports such as coffee, hides and skins, oilseeds and pulses. From the total exports of the country coffee was the dominant export commodity accounting for about 52.27 per cent of the country's total exports, on average for the last decade. 
Spices are essential oils that give foods and beverages flavor, aroma and sometimes color. The term spice refers to any dried plant product used primarily for seasoning, be it the seed, leaves, bark or flowers. They can be marketed whole, ground to a powder or in the form of essential oils and oleoresins. Many spices are also used for other purposes. Plants such as turmeric (Curcuma longa) are increasingly in demand for natural therapies, while others such as peppers (Capsicum spp.) serve as substitutes for chemical dyes or pesticides (Masresha, 2010).

Ethiopia is a homeland for many spice crops spices, such as Aframonum Korarima (Korarima), Long Pepper, Black cumin, White cumin /Bishops weed ('Nech azmud')/, Coriander and Ginger. As a result, the history of spice use in Ethiopia is an ancient one and spices have always been and remain as basic food items in the diet of the Ethiopian people. For instance, Hot Pepper (berebere) of Ethiopia is a must for the traditional and most staple food 'wot' in many parts of the country. In relation to this, the preparation of Pepper flour also involves use of mix of different type of spices (Ethiopian Investment Agency, 2013). According to Ministry of Agriculture report of 2010, the country has reached to production level of spice crops 244,000 ton/annum having area coverage of 122,700 hectares. The seed spices potentials area are Amhara and Oromiya regions while for the low land spices dominantly produced and potential in SNNP and Gambella regions; In general the total potential for low land spices is estimated to be 200,000ha.

The major constraints facing the spices sub sector of Ethiopia covers production and marketing stages. In the Production Stage, the following are the major challenges: low level of availability of improved and high yielding varieties; poor quality of processed products in international market; very low involvement of private investors on commercial spice crop production; the supply of raw spice to processors from forest and backyard is very low and irregular; high wastage due to poor post harvest handling practice ; lack of incentives for farmers as well as processors from the government; low effort made to adapt forest species which can help for afforestation; unavailability of clearly defined farm management practices for species of spices and Lack of appropriate spices development strategic interventions are the major problems. Similarly, there are several problems in marketing stages. Among the major challenges: poor storage facility for looking better price; trust losing among actors due to mixing poor quality products; products of low quality dominate the market because of traditional way of value adding; mixing water with the product at different stage of market for looking high weight; evils of middlemen in the marketing are very high; unavailability of price awards for quality products; bulky nature of products appears in majority of market places which demands value adding activity; irregular nature of demand and supply which leads to price volatility; information asymmetry on prices at different market places and stages; loose market research particularly assessing the international demand and poor promotion on marketing are the major ones are listed based on level of importance (Masresha, 2010). However, the efforts of different local scholars so far made on identifying different challenges both production and marketing there is a gap on studying export performance of the country. Thus, this piece of work tried to narrowing this gap.

The objective of this study is to examine spice crops export performance in Ethiopia. This paper is organized as follows: section 2 provides literature reviews, including theoretical and empirical evidence on Determinants of spice crop export performance. Section 3 discusses model specification, data source and description, estimation techniques. Section 4 presents analysis and results of the study. Finally, section 5 presents conclusion and policy implication based on the estimated results.

\section{Literature review}

Least developed countries characterized by low productivity and quality products, poor pre and post harvest agricultural product handling as well as processing, lack of better market access, poor storage facilities and transportation logistics, deforestation and gender disparity. Moreover, due to a shortage of income and lack of access to improved agricultural technologies, the small holder farmers particularly wives of farmers and female headed household have experienced limited benefit from the annual return of sale of major agricultural commodities. Besides, the outstripping population growth in major spice and aromatic production regions exacerbates the socio economic problem and food aid dependency of the smallholder farmers and women (FAO, 2016). In order to reduce poverty and food dependency of these smallholder farmers and women in Ethiopia via enhancing their purchasing power, it is apt to create competitive, efficient and effective spice, herbs and aromatic plants value chain service delivery mechanism. Other countries such as China, India, Bangladesh, Nigeria, Indonesia and Vietnam experiences showed it is conceivable to overcome the multi sectoral constraints of spice, herbs and aromatic sector through establishing proactive, strong and legitimate membership based platform (Addisu, 2014).

According to Stephen (2017) Exchange rate has a direct relationship with factors such as foreign direct investment, inflation, interest rate, and similar macroeconomic variables, but it worth noting that little or no emphasis has been given to the critical relationship between exchange rate and export growth in the Nigerian context. Some other research result has also indicated that exchange rate is significant in influencing not only export growth (Omojimite, 2012) indeed several other economic sectors, interest rate, inflation, FDI, and agricultural production (Chukuigwe and Abili, 2008; Alao, 2010; Wafure and Nurudeen, 2010; Enoma, 2011; 
Ajide, 2014) but EXP growth as a variable was excluded from many of these investigations, hence the present attempt to fill-in the gap. It is further observed that many of the past studies harped on the agricultural sector as the largest employer of labour in Nigeria.

The other factor affecting export performance is degree of openness to trade. Opening economic policies to trade with the rest of the world is needed for export and economic growth. This is because in recent decades there is no country achieving economic success in terms of substantial increases in living standards for its people without liberalizing itself to the rest of the world. Trade liberalization has generally taken place in LDCs as part of the structural adjustment program (Belayneh et al, 2013). Trade liberalization implies considerable reduction in tariff and non-tariff barriers, so as to establish a noticeable open market as compared with the preliberalization era. The empirical researches focusing on the impact of trade liberalization (openness) on export earnings have exhibited positive results. For example literatures show that countries which get on liberalization programs have improved their export earnings (Ahmed, 2000). Similarly, Seyyed et.al (2011), using panel data evidence for 19 countries found that open trade policy enhances GDP and export growth. Using these results clearly prefer open trade policy over more trade barrier which enhance GDP and export growth. Conversely, Giovani and Levencko, (2007) argue that increased trade openness has contributed to rising uncertainty and exposed countries to external shocks and hence, adversely affects country's export.

The share of total expenditure of household income of spice was assessed by the central statistics agency of the country by the year 2005 . Accordingly, it took the share of $1.79 \%$ of the expenditure of the household which dominated by paper whole and flour, followed by ginger, fenugreek, and then cinnamon, chilies, long pepper and mixed spices. Its share of household expenditure for rural Ethiopia was higher at $1.87 \%$, while the share for Urban Ethiopia was $1.46 \%$. The survey result by CSA shows, spices has $1.08 \%$ and $1.11 \%$ share of total net and gross calorie per capita per day. The net calorie per capita per day for rural and urban areas of Ethiopia is $9.69 \%$ and $1.63 \%$ respectively, while the gross calorie per capita per day is $0.99 \%$ for rural and $1.94 \%$ for urban Ethiopia (CSA,2005).

Export (Xit): The annual values (in USD million) of Ethiopian spice crop exports to each of the 10 main trading partners are mainly collected from FAOSTAT Data Base. Gross Domestic Product (GDPit and GDPjt): Data on GDP of Ethiopia and its trading partners (in million US dollars) are collected from World Bank Data Base. Given that spice crop exports are the difference between domestic supply and domestic demand, they should be affected by the growth in domestic income. It may be the GDP of the Ethiopia or its trade partner. GDP of Ethiopia (GDPit) is source of power for increasing the export. Given this, the foreign GDP (GDPit) also would result into increment in the export of coffee by being source of demand. Both of the two GDP are source of enlarging the spice export of Ethiopia, implies that two of the variables are expected to have positive contribution for the expansion of the export. Real Exchange Rate (RERijt) is the real bilateral exchange rate between country $i$ and country $j$ at time $t$ measured by the formula: $\mathrm{RER}_{\mathrm{ijt}}=\left(\mathrm{TCN}_{\mathrm{i}} / \$ / \mathrm{TCN}_{\mathrm{j} / \$}\right) \mathrm{X}\left(\mathrm{CPIj} / \mathrm{CPI}_{\mathrm{i}}\right)$ where TCN is the nominal exchange rate vis -a -vis the dollar and CPI is the price index, notably the GDP deflator. The data are available from EEPRI Data Base. The negative impact of the real bilateral exchange rate will be reflected in $\beta 2<0$.

\section{Data and Methodology \\ Data Source and Type}

In this study, time series secondary data has been used. The data set has been collected from FAOSTAT, IMF database and CoMTRADE data source. For the purpose of analyzing the country's determinants of spice crop export performance, the export equation has been estimated using time series data for the period 1992/93$2015 / 16$. STATA software was utilized to analyze the secondary data obtained from different sources.

The time series data that are used in this study are export of spice crops valued in US dollar, real income of trading partner (average real GDP of 10 major trading partners (India,Isreal,Kenya,Norway,Saudi Arabia, the former Sudan, UAE, UK, USA and Yemen) which accounts about 80 percent of Ethiopia's spice export destinations) valued in USD, real GDP of home country valued in USD and openness (calculated using the sum of export and import of goods and services as a ratio of GDP) are collected from World Bank (2018). Data for real effective exchange rate is collected from Ethiopian Economic Association(EEA) statistical data base CDROM (2018) and Nation Bank of Ethiopia (2018) and checked to World Bank data for consistency. Government expenditure for transportation and communication is calculated by taking both capital and current expenditure for communication and transportation including road. Since the researcher did not find data for such variables from IMF and WB data source, these variables are collected from both NBE (2018) and EEA statistical data base CD-ROM (2018).

\section{Econometrics Model specification}

This study focuses on demand side determinants of Ethiopia's spice crop export performance. Therefore, the study signifies Ethiopia's spice export performance as a function of real GDP of home country, real effective 
exchange rate, and openness for trade, infrastructural development and financial development. The model that has been used in this paper is adopted from Goldestien and Khan (1985) imperfect substitution model which is expressed as follows:

$\mathrm{EX}=f(\mathrm{RGDPTP}, \mathrm{REER}, \mathrm{OPEN}, \mathrm{RGDP}, \mathrm{TCEX})$ $-1$

A log-linear form of spice crop export determination model is employed to determine Ethiopia's spice crop export performance. The model is therefore similar to the one used by Amin (2007) in estimating determinant of cut flower export in Ethiopia and Hailegiorgis (2011) in estimating export performance of oil seeds in Ethiopia. Therefore, the regression equation is given by:

$\ln \mathrm{EX}=\alpha+\mathrm{B}_{1} \ln \mathrm{RGDPT}+\mathrm{B}_{2} \operatorname{lnREER}+\mathrm{B}_{3} \operatorname{lnRGDP}+\mathrm{B}_{4} \operatorname{lnOPEN}+\mathrm{B}_{5} \ln \mathrm{TCEX}+\varepsilon_{\mathrm{t}}-\cdot-\cdot-\cdot-\cdot-\cdot-\cdot---2$ Where,

$\mathrm{EX}=$ Spice Export earnings at time $\mathrm{t}$ in log form is the dependent variable

RGDPTP $=$ the real GDP of our trading partners (about 80 percent of Ethiopian spice export destination countries) $\mathrm{REER}=$ Real Effective Exchange Rate in log form (which is found by trade weighted Birr/foreign currency)

$\mathrm{OPN}=$ Exports plus imports as a percentage of GDP, a proxy for degree of openness in log form

RGDP $=$ Real GDP at home country in log form

TCEX $=$ Public expenditure in transportation and communication as a ratio of GDP as a proxy for infrastructural development in log form.

$\varepsilon_{\mathrm{t}}=$ Error term

In analyzing determinant of spice export performance based on available literature on demand side, first three variables in the model are called external. Ethiopia is one of the countries whose export performance depends on overseas economic situation. As the country is economically a small open price taker in the world market. World market forces, generally determine the prices of its exports. Therefore, overall income of trading partner affects spice export performance of Ethiopia directly. That is, all other things remain constant; an increase in the real GDP of Ethiopia's major trading partners, which is denoted by , either due to the output growth of our major trade partners, liberalization measures, or diversification measures increases the demand for our product and hence increase Ethiopia's export earnings $\left(\mathrm{B}_{1}>0\right)$.

The movement in value of spice export also correlates with relative prices. In theory, real effective exchange rate movements are also negatively correlated with the growth in spice exports performance. Thus, the expected sign of the REER coefficient is ambiguous. This is because it depends on the exchange rate regime that the country experiences. According to the Marshal-Lerner condition and Mundel-Fleming model, a decrease in real effective exchange rate or appreciation of domestic currency will make exportable items costly, then the demand for our exports in external market is likely to fall and this in turn will reduce foreign exchange earnings. In such a case, the expected sign of real effective exchange rate (REER) will be positive (i.e $\mathrm{B}_{2}>0$ ). The reverse is likely to occur (i.e. $\mathrm{B}_{2}<0$ ) if the increase in real exchange rate (devaluation) worsens export by increasing cost of spice export by decreasing the country's competitiveness in international market.

The third variable (Real GDP) regarded as internal (supply side) determinants of spice export earnings. The inclusion of real output of spice in the model is based on the argument that the output capacity of an economy is an indication for future supply capacity. Thus, an increase in output will enhance export earnings $\left(\mathrm{B}_{3}>0\right)$.

The impact of trade openness of the country is very much ambiguous as reviewed in literature part of this article. Accordingly, some scholars argue that there is direct and positive association of trade openness with getting more volume of foreign exchange. The implication is that a country needs to integrate to the world market by diversifying its trading partners. The degree of integration of a country to external market is thus measured by openness to trade, which is proxied by the sum of exports and imports of goods and services to GDP ratio. Thus, an increase in the ratio of exports and import of goods to GDP (or) implies better integration of Ethiopia to the external world and hence higher export earnings. In short, an increase in openness will have positive impact on export performance OPN (or $\mathrm{B}_{4}>0$ ). However, if openness leads to shocks in the goods market that declines in export demand, it will decrease exports earnings $\left(\mathrm{B}_{4}<0\right)$.

Economic theory also strongly acknowledges that the quality of infrastructure is one of the key determinants of spice export performance. Infrastructure (road, electric power, telecommunication, etc) development, which is the key determinant factor for the flourishing of any industry especially export sector is proxy by the ratio of public investment on transportation and communication to GDP (TCEX). Therefore, expanding infrastructure density of various types with an acceptable level of quality or the increase in public investment in infrastructure to GDP ratio $(T C E X)$ in Ethiopia will have positive impact on export growth. That is, the expected sign of $(T C E X)$ is positive (or $\left.\mathrm{B}_{5}>0\right)$.

\section{Estimation Technique}

Therefore, the primary task in time series econometric analysis is undertaking unit root test on the variable of interest. The test examines whether the data series is stationary or not. To conduct the test, the conventional Dickey-Fuller (DF) and Augmented Dickey-Fuller (ADF) test has been used with and without a trend. Since the 
actual data generating process is not known a priori, the test of determining the orders of integration of the variables has conducted first by including a constant only and then both a constant and a trend. The ADF test is based on the regressions run in the following forms.

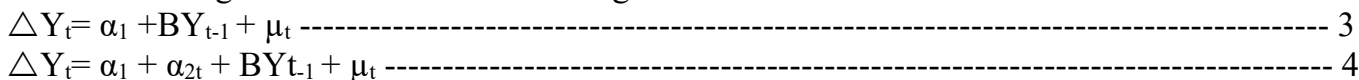

Where, $t$ is the time or trend variable. Equation (3) adds a drift, and equation (4) introduces both a drift and a time trend. In each case the null hypothesis is that $\mathrm{B}=0$, that is, there is a unit root. The null hypothesis $\left(\mathrm{H}_{0}\right)$ is thus a series contains a unit-root (non-stationary) against the alternative hypothesis $\left(\mathrm{H}_{1}\right)$ stationary (deterministic trend). Even though the individual time series are not stationary, a linear combination of these variables could be stationary (i.e. they may be co-integrated). If these variables are co-integrated, then they have a stable relationship and cannot move "too far" away from each other.

The set of variables to be included in a VAR is determined by the economic problem at hand. There should be test for Stationary of the variables which Pre-test all variables to assess their order of integration. Plot the variables to see if a linear time trend is likely to be present in the export of spice crops in Ethiopia. You also need to test for stationarity along the lines of Pantula principle. The lag length can be determined by some of the information criteria procedures. It is important to avoid too many lags, since the number of parameters grows very fast with the lag length. Then you should run Deterministic Trend Specification of the VECM.

There is a procedure of testing the actual number of co integrating vectors by using maximum Eigen values and trace statistics. Estimation and determination of rank is very important. The test of rank is done in specific order from the largest Eigen value to the smallest. We use the "Pantula Principle" where we test for significance until you no longer reject the null. The variables may have nonzero means and deterministic and/or stochastic trends. Similarly, the co integrating equations may have intercepts and deterministic trends. The best way to do VAR in non-stationary world is to test for co integration using Johansen. After that we have to use the Granger representation theorem to express the relationship as a vector error correction model (VECM).

A vector Error Correction (VEC) model is a restricted VAR designed for use with non-stationary series that are known to be co integrated. The VEC has co integration relations built into the specification so that it restricts the long run behavior of the endogenous variables to converge to their co integrating relationships while allowing for short-run adjustment dynamics. The co integration term is known as the error correction term. Since the deviation from long-run equilibrium is corrected gradually through a series of partial short-run adjustments. As the VECM specification only applies to co integrated series, you should first run the Johansen co integration test and determine the number of co integrating relations.

There are two common methods for testing co-integration and estimating the relationship among cointegrated variables. These are the Engle and Granger (1987) two-step procedure and the Johansen's (1988) maximum likelihood methods. The Johansen procedure takes care of the above shortcomings by assuming that there are multiple co-integrating vectors. Thus, testing for co-integration using the multivariate VAR approach developed by Johansen (1988) is necessary because failure to capture the existence of more than one cointegrating vector yields misleading long-run coefficients. In which case, the estimated parameters of the long run coefficient would only be a linear combination of the parameters of the two or more co-integrating long-run relationship (Harris, 1995). Thus, an unrestricted VAR can be formulated to estimate the long run relationship among jointly endogenous variables. The co integration regression so far considers only the long-run property of the model and does not deal with the short-run dynamics explicitly. Clearly, a good time series modeling should describe both short-run dynamics and the long-run equilibrium simultaneously. Finally, whether the long run parameters are obtained using the Johansen co integration analysis, the Johansen (1988) Vector Error Correction Model (VECM) has been estimated (Belayneh et al, 2013).

\section{Analysis and results}

The primary task in VAR model analysis is stationary test. It is well known that the VAR analysis may depend critically on the lag order selection of the VAR model. Usually, different lag order can affect the interpretation of the VAR estimates when those differences are large enough. The most common strategy in empirical studies is to select the lag order by some pre specified criterion and to condition on this estimate in constructing the VAR estimates.

The value depicted in table 1 of Dickey Fuller test clear that the null hypothesis of a unit root is rejected for value of foreign currencies earned per year (valuepyear) variable with a drift term (constant). The test results of the other variables are the same as displayed on attached in the annex. Hence the value of test statistics in Absolute value is less than 5 percent critical value in the same absolute value. Thus, we reject the null hypothesis of the yearly value of earning has unit root or not stationary. Moreover, the null has been rejected for lag one of all variables at five percent level of significance. Therefore, it is possible to conclude that the variables are integrated of order one. 
Table 1. Result of Dickey Fuller test for unit root test at the first difference of the variable

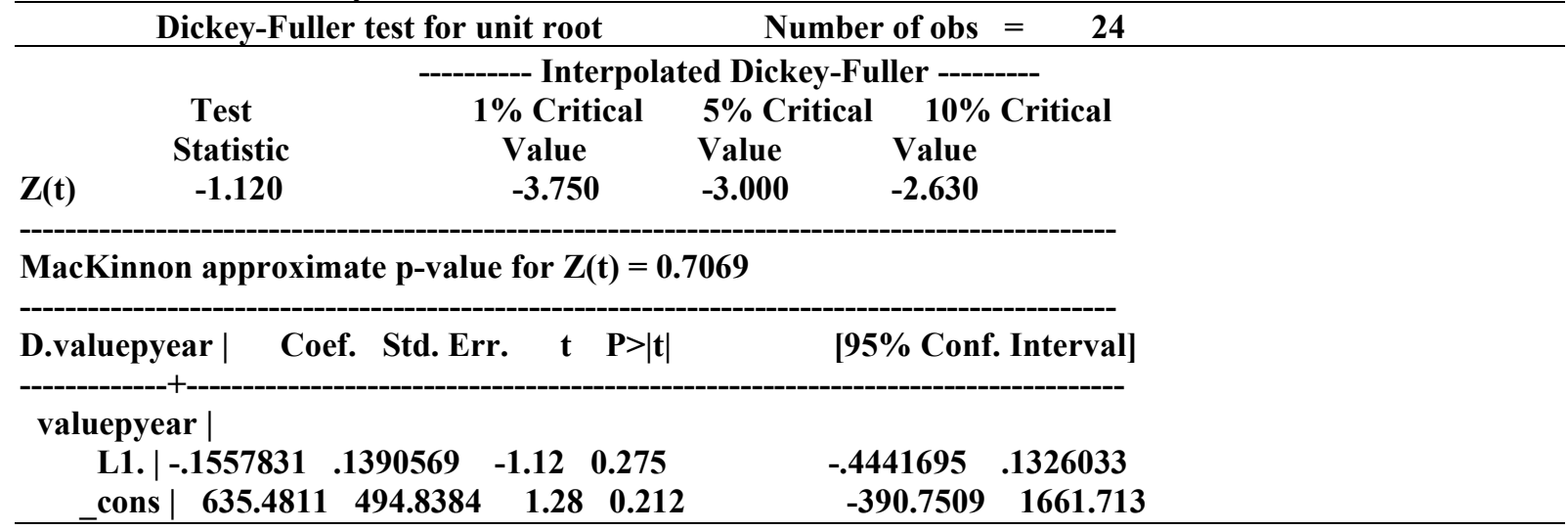

Table 2. Results of Augmented Dickey Fuller test for unit root test at the first difference of the variable

\begin{tabular}{|l|c|c|c|}
\hline \multirow{2}{*}{ Variables } & \multicolumn{2}{|c|}{ Augmented Dickey Fuller } & \multirow{2}{*}{$\begin{array}{c}\text { Order of } \\
\text { integration }\end{array}$} \\
\cline { 2 - 3 } & \multicolumn{2}{|c|}{ Lag length 1 } & I \\
\cline { 2 - 3 } & $-4.7899^{* *}$ & $-4.5714^{* *}$ & $1(1)$ \\
\hline$\triangle$ LEX & $-4.7862^{* *}$ & $-4.6597^{* *}$ & $1(1)$ \\
\hline$\triangle$ LRGDER & $-4.8491^{* *}$ & $-4.1311^{* *}$ & $1(1)$ \\
\hline$\triangle$ LOPN & $-5.2611^{* *}$ & $-5.3055^{* *}$ & $1(1)$ \\
\hline$\triangle$ LRGDP & $-4.6614^{* *}$ & $-5.5437^{* *}$ & $1(1)$ \\
\hline$\triangle$ LTCEX & $-5.7083^{* *}$ & $-6.6014^{* *}$ & \\
\hline
\end{tabular}

Note: $* *$ denotes rejection of the hypothesis of unit root in the first difference of variable at $1 \%$. Significance level for ADF statistic

As illustrated in the order of integration results in Table 2 above, all variables are non-stationary and integrated of order one, I(1). This result is supported by the research finding of Alemu et al (2003) in which estimating maize supply response using adaptive expectation and partial adjustment models would lead to spurious regression. They also pointed out that spurious regression and inconsistent and indistinct short-run and long-run elasticity estimates are the major pitfalls of the traditional Nerlovian supply response models.

The test result obtained by using Johansen (1988) of SBC \& AIC criterions showed in table 3 below, the lags $(\rho)$ of VAR model and other criterion the order of VAR is 1 . This result also repeated by other criterion. Thus, the lag $(\rho)$ of 1 was used in the model as the order of VAR.

Table 3. Lag length Selection

\begin{tabular}{|c|c|c|c|c|c|c|}
\hline & & FPE & AIC & SC & HQ & LR \\
\hline 0 & 38.77408 & - & $3.37 \mathrm{e}-10$ & -1.767308 & -1.379444 & -1.657799 \\
\hline 1 & 373.3145 & $445.8234^{*}$ & $4.92 \mathrm{e}-15^{*}$ & $-12.51066^{*}$ & $-10.67374^{*}$ & $-12.29107^{*}$ \\
\hline 2 & 318.7098 & 57.09098 & $6.88 \mathrm{e}-15$ & -13.02036 & -8.194538 & -11.78940 \\
\hline
\end{tabular}

Note: * indicates lag order selected by the criterion calculated using EViews-7

FPE: Final Prediction Error

AIC: Akaike Information Criterion

SC: Schwarz Information Criterion

HQ: Hannan-Quinn information Criterion

LR: Sequential modified LR test statistic (each test at 5\% level)

The Stata result of testing co integration among proposed variables that determine annual return from export of spice crops revealed that the maximum value is greater than critical value at zero co-integrating vector $(r=0)$ for both trace test and Maximum-Eigen value test. This indicated the existence of one co-integrating relationship. Thus, the null hypothesis of no co-integration is rejected at the conventional level (0.05) and the study concluded that there exists a relationship among the proposed variables in the long run(Table 4). Trace test and Eigen value test indicates that there are two co-integrating vector. All the variables are co-integrated of order one having the long run relationship. 
Table 4. Johansen's Co integration Test

\section{Johansen tests for co-integration}

Trend: constant

Sample: 1994 - 2016

Number of obs $=$

Lags $=2$

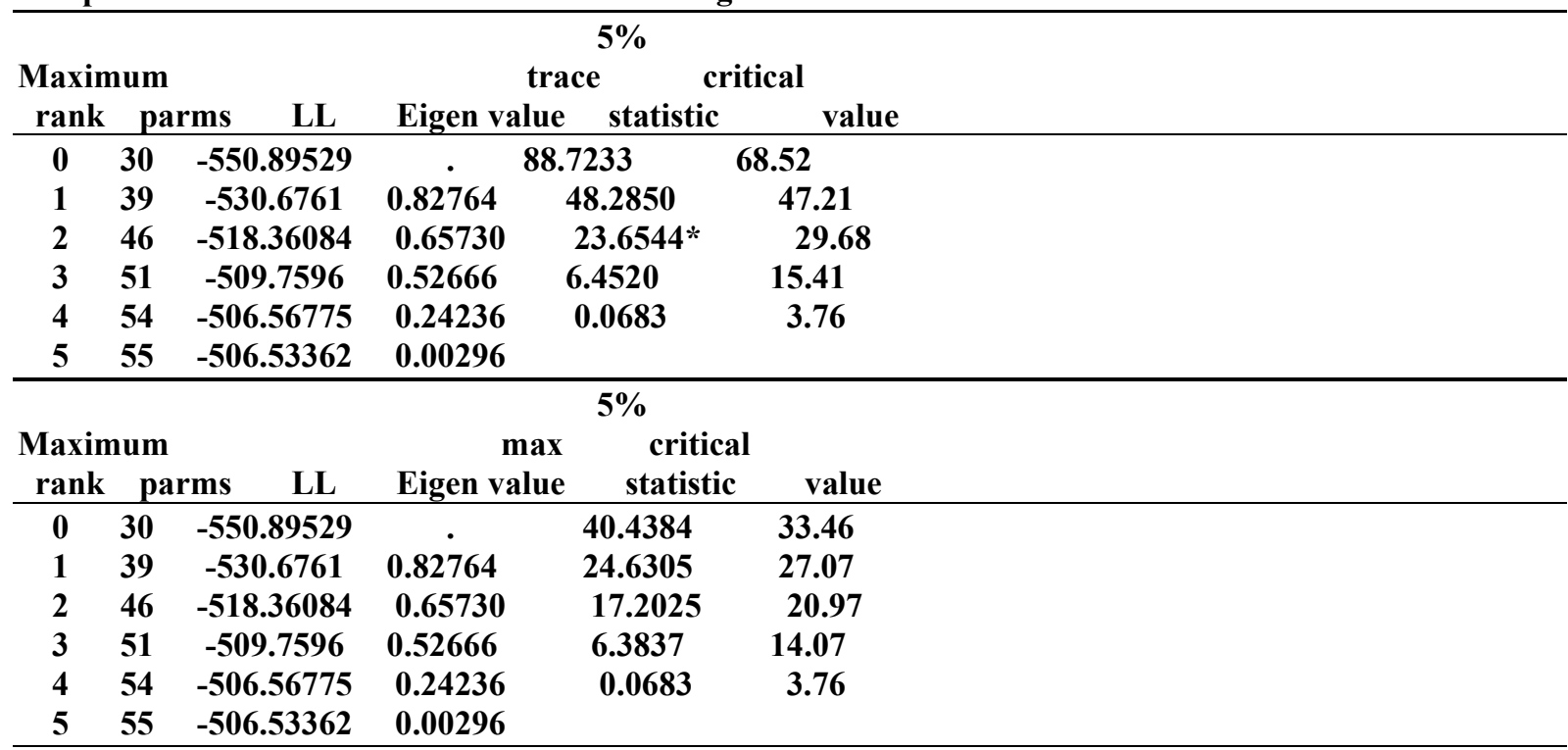

Note: *denotes rejection of the hypothesis at 5 per cent significance level.

The next procedure after identifying order of co integration for each variable that enters the specified model of spice crops export determination is estimating the long run relationship between Ethiopia's spice crops export performance and it determinants using the Johansen (1988) maximum likelihood method. The maximum likelihood statistics method is important for estimating consistent estimates of the long run parameter which could be tested using likelihood ratio (LR) statistics.

As displayed in table 5 below, the level of significance varies among parameters for earning from export of spice crops in the country. Accordingly, real effective exchange rate, openness to external trade and real GDP are significant at 5 percent level of significance.

Table 5. Normalized co-integration coefficients (Standard errors in parenthesis)

\begin{tabular}{|c|c|c|c|c|c|c|}
\hline LEX & LRGDPTP & LREER & LOPN & LRGDP & LTCEX & constant \\
\hline \multirow{2}{*}{1.000000} & -0.120774 & -0.785507 & -0.583535 & -1.655999 & -0.400267 & - \\
& $(0.23496)$ & $(0.06512)$ & $(0.07817)$ & $(0.14430)$ & $(0.11531)$ & 17.956978 \\
\hline t-statistics & 0.514019 & 12.062454 & 7.464948 & 11.476084 & 3.471225 & - \\
\hline
\end{tabular}

Note: ** Significance at $5 \%$ and $*$ significance at $10 \%$.

The impact of increase in per capita income of Ethiopia's trading partner nations (GDPTP) is insignificant on demand of spice crop export. Moreover, the finding supports Fugazza (2004), who argued the growth of trading partner income will not drive movements in developing countries exports.

Different variables were tested for their significance on export of spice crops. Accordingly the effect of real effective exchange rate had impact on export level of the country as depicted in table 4 a one percent increase of this variable results a 0.7 percent change in total export earnings. It is well known that exports of LDCs are price inelastic in the international market due to nature of the product that LDCs produces. The positive and significant coefficient also shows that export may be influenced by exchange rate policy. This idea is more elaborated by the concept of devaluation of birr in terms of foreign currency improves price competitiveness of spice crop export and hence leads to an increased export performance of Ethiopia.

The value of trade openness showed that a one percent trade liberalization (openness) positively influence by increasing 0.58 percent of Ethiopian spice crop export performance. The theoretical expectation of trade liberalization has a consistent idea with the result of this research outcome. It also supported by empirical evidence Mouna(2001) who declared the importance of trade liberalization programs that improved export earnings.

Export earning and the growth of RGDP move in similar direction in accordance with macroeconomic theories. The coefficient of real growth domestic product for home country is 1.656 which means that a one percent change on real GDP of home country results 1.656 percent increase in total export earnings. This is consistent with Ahmed and Majeed(2006) in estimating developing countries export. They found that GDP of home country affects their export positively. This is due to the fact that output capacity of an economy has 
implication of supply capacity by maintaining a country's competitiveness in the international market in the long run.

The Short Run Error Correction Model

The speed of adjustment term (Table 5) is the most important idea in short run. This term depicted that how much time is required to be reached in long term equilibrium. The sign of speed of adjustment has indication which Negative sign of speed of adjustment term shows that the economy will converge towards long run equilibrium. But if it is positive, the economy will not converge to the long run equilibrium.

The Vector Error Correction Model (VECM) result in Table 6 below shows that only one variable affects the Ethiopian export performance in the short run.That is only openness in the previous year affects current export in the short run. The more trade liberalization in the previous year the more export would be. This may due to the fact that the more the economy is integrated to the rest of the world; it has immediate response to enhance the country's export. Here the adjustment coefficient is negative which shows that the variable will converge towards long run equilibrium after taking around 61 percent annually adjustments in the short run. As can be seen from the diagnostic tests above, the hypothesis of the non-existence of serial correlation, the presence of normality and the existence of homoscedasticity are not rejected for the Export performance error correction specification.

Table 6. Results for VECM estimates

\begin{tabular}{|c|c|c|c|c|}
\hline \multicolumn{5}{|c|}{$\triangle \operatorname{lnEX}$} \\
\hline Variables & Coefficient & Std Error & t-statistics & Prob. \\
\hline DLREER & 0.342569 & 0.193245 & 1.772719 & $0.0841 *$ \\
\hline DLOPN & 0.398764 & 0.139874 & 2.85088 & $0.0077 * *$ \\
\hline DRGDP & 0.365479 & 0.357102 & 1.023458 & 0.3124 \\
\hline DLTCEX & 0.197207 & 0.122459 & 1.610392 & 0.1205 \\
\hline DLEX & 0.044671 & 0.188456 & 0.237037 & 0.6755 \\
\hline $\mathrm{C}$ & 0.033143 & 0.023145 & 1.384047 & 0.1574 \\
\hline ECM_1 & -0.605045 & \multicolumn{2}{|c|}{ Mean dependent VAR } & 0.083244 \\
\hline R-squared & 0.529381 & \multicolumn{2}{|c|}{ S.D. dependent VAR } & 0.197699 \\
\hline Adjusted R-squared & 0.435370 & \multicolumn{2}{|c|}{ Akaike info criterion } & -1.259806 \\
\hline S.E. of regression & 0.119950 & \multicolumn{2}{|c|}{ Schwarz criterion } & -0.917663 \\
\hline Sum squared residual & 0.492021 & \multicolumn{2}{|c|}{ Hannan-Quinn criter. } & -1.176471 \\
\hline Log likelihood & 32.885467 & \multirow{2}{*}{\multicolumn{2}{|c|}{ Durbin-Watson stat }} & 2.379945 \\
\hline F- statistic & 5.218824 & & & \\
\hline Prob(F-statistics) & 0.000457 & & & \\
\hline \multicolumn{5}{|l|}{ Model Diagnostic test } \\
\hline \multicolumn{5}{|c|}{$\begin{array}{l}\text { Normality test: } \quad=2.951461[0.284719] \\
\text { LM test for serial correlation }=0.1560[0.0878]\end{array}$} \\
\hline
\end{tabular}

Note: ECM-1 is the lagged residual saved from the estimated long run equation

Conclusion and Policy Recommendation

The overall analysis of Ethiopian spice crop export performance of the country for the period 1992-2016 was addressed in this paper. The method applied to assess the impact of spice crop export on economic development was time series econometric analysis. In this analysis method, Johansson co-integration methodology was employed in order to know the long and VECM short run determinants. The empirical finding and evidence from other scholars on export performance of a given country; Ethiopian spice crops export determination model confirms that, real GDP of home country, real effective exchange rate, and trade are positive and significant determinants of country's export of these crops. Variables on trading partners (importers) were assessed for testing its impact on trading. Accordingly, Real GDP of trading partners was found to be statistically insignificant to determine Ethiopia's spice crop export in the long run. Among the abovementioned variables only trade liberalization (openness) was found to be the only determinant of country's spice crop export in the short run. It is found to be positive and statistically significant where as the rest variables are found to be statistically insignificant.

The export of Ethiopian spice crop competitiveness also dependent on the effectiveness of real exchange rate. Thus, the government should work hard to keep stable the rate of exchange rate. This can be done by allowing timely and reasonably depreciation of Birr in the long run for encouraging export. The act of trade liberalization from the government side plays a significant role base on the minimum requirement of world trade organization for better involvement of local as well as international investors on spice sector. The overall 
infrastructure development like telecommunication service and road should be give due attention to get better return from export of spice crops. The production level of spice crops nationwide is very low which should be given a priority by motivating farmers at consecutive levels of production.

\section{References}

Addisu Alemayehu ,2014. Spice, Herbs and Aromatic plants subsector platform meeting report, pp 8-9 .

Agosin, R. (2007), "Export Diversification and Growth in Emerging Economies", Working Paper No. 233. Departamento de Economía, Universidad de Chile.

Ahmed, E. and Majeed, M. (2006), "Determinants of export in Developing Countries", The Pakistan development review. 45: 4 pp.1265-1276

Ahmed, U. (2000), "Export Responses to Trade Liberalization in Bangladesh: A Co-integration Analysis", Applied Economics, 32, 1077-1084.

Ahmed, E. and Majeed, M. (2006), "Determinants of export in Developing Countries", The Pakistan development review. 45: 4 pp.1265-1276

Ajide, K.B., 2014. Determinants of economic growth in Nigeria. CBN Journal of Applied Statistics, 5(2): 147 170. View at Google Scholar

Alao, R.O., 2010. Interest rates determination in Nigeria: An econometric x-ray. International Research Journal of Finance and Econometrics, 47: 43-52.

Alemayehu G. (2006), "Openness, Inequality and Poverty in Africa”, DESA Working Paper No. 25

Alemu, Z.G., K. Oosthuizen\& H.D. van Schalkwyk. 2003. Grain-supply response in Ethiopia: An errorcorrection approach.Agrekon, vol. 42, pp. 389-404.

Amin A. (2007), "The booming non-traditional export commodities: The case of cut- flower", Paper presented for the 5th annual international conference on Ethiopian economy, EEA, AA.

Bacchetta, M. (2007), "Releasing Export Constraints: The Role of Governments", AERC Research Project on Export Supply Response Capacity Constraints in Africa, Paper No. ESWP 01

Belayneh Kassa and Wondaferahu Mullugeta. 2013. DETERMINANTS OF EXPORT PERFORMANCE IN ETHIOPIA: VAR MODEL ANALYSIS. National Monthly Referred Journal of Research in Commerce \& Management. Volume No.2, Issue No.5. PP 97-99

Biggs, T. (2007), "Assessing Export Supply Constraints: Methodology, Data, and Measurement", AERC Research Project on Export Supply Response Capacity Constraints in Africa, Paper No. ESWP 02

Chinn, M. and Prasad, E. (2003), "Medium-Term Determinants of Current Accounts in Industrial and Developing Countries: An Empirical Exploration, Journal of International Economics, 59(1), 47-76.

Chukuigwe, E.C. and I.D. Abili, 2008. An econometric analysis of the impact of monetary and fiscal policies on non-oil exports in Nigeria: 1974 - 2003. African Economic and Business Review, 6(2): 59-73. View at Google Scholar

CSA,2005. The House Hold Income, Consumption And Expenditure Survey -HHICES Report. PP 25-27.

Dana Dascal, Konstadinos Mattas and Vegelis Tzouvelekas (2002), 'An Analysis of European

Union Wine Trade: A Gravity Model Approach',Greece.

Engle, R. and Granger C. (1987), "Co-integration and Error Correction: representation, Estimation, and Testing", Econometrica. Vol.55 (92), pp.251-276

Enoma, I.A., 2011. Exchange rate depreciation and inflation in Nigeria (1986-2008). Business and Economics Journal, 28: 1-11.

Ethiopian Investment Agency, 2013. Annual report of spice production and marketing in Ethiopia. Volume I, PP 5-6.

Food and Agriculture (FOA), 2016. Annual Report on World spice crops production and consumption, Rome Italy. PP 36-37.

Fugazza, M. (2004), "Export Performance and Its Determinants: Supply and Demand Constraints", Policy Issues in International Trade and Commodities Study Series No. 2

Giovanni .J. and Levnchenko A. (2007), “Trade Openness and Volatility”, Review of Economics and Statistics, 91:3 (August 2009), 558-585.

Goldstein, M. and Khan, S. (1985), "Income and price effects in foreign trade", in R. Jones and P. Kenen (eds), Handbook of International Economics, vol. II, North-Holland, Amsterdam.

Hailegiorgis B. (2011), "Export performance of oil seeds and its determinants in Ethiopia" Journal of serials and oil seeds, Vol.2 (1), pp.1-15

Harris, R. (1995), "Cointegration Analysis in Econometric Modeling”, London, University of Portsmouth, Prentice Hall.

Johansen, S., (1988), "Statistical Analysis of Co-integration Vector", Journal of Dynamics and Control, Vol.12, pp.231-254

Lehman F. and Zarzeso M. (2002), 'Augmented Gravity Model: An Empirical Application to Mercosur- 
European Union Trade Flows' (can be accessed at www.lacea.org/meeting2001/kumil.pdf)

Masresha Yimer,2010. Market profile on spices; Ethiopia, to UNCTAD ITC, Addis Ababa, PP 3-4.

Ministry of Agriculture, 2010.Agricultural Investment Potential of Ethiopia, MOARD, March 2010.Assesement report - PP 8-9.

Mouna, C, and Ahmad R. (2001), "Trade Liberalization, Real Exchange Rate, and Export Diversification in Selected North African Economies", First Draft

NBE (2011), National Bank of Ethiopia Annual Report, Addis Ababa

NBE (2016), National Bank of Ethiopia Annual Report, Addis Ababa

Omojimite, B.O., 2012. Institutions, macroeconomic policy and growth of agricultural sector in Nigeria. Global Journal of Human Social Science, 12(1): 1-8. View at Google Scholar

Seyyed H. Maysam M., Shahab A., and Mehran N., (2011), "GDP, Openness and Export Causality” A Panel VAR Approach using Commodity Disaggregated”, International Bulletin of Business Administration, ISSN: 1451-243X Issue 12

Stephen Aro-Gordon, 2017. Econometric analysis of exchange rate and export performance in developing economy. Asian Economic and Financial Review. 7(4): 334-348.

Wafure, G.G. and A. Nurudeen, 2010. Determinants of foreign direct investment in Nigeria: An empirical analysis. Global Journal of Human Social Science, 10(1): 26-34. View at Google Scholar

World Bank, 2015 . Annual report of the year 2009/2010. PP 3-4. 